\title{
BAMBI ARI' SEBAGAI WUJUD KEARIFAN LOKAL MASYARAKAT DAYAK DALAM PENANGANAN BENCANA KABUT ASAP DI KABUPATEN KAPUAS HULU, KALIMANTAN BARAT
}

\section{Muryanti, Rokhiman}

Prodi Sosiologi, Fakultas Ilmu Sosial dan Humaniora, UIN Sunan Kalijaga newsyant@yahoo.com

\begin{abstract}
The massive scale of forest fire by big companies in Kapuas Hulu have caused smog disaster that affect surrounding areas suh as Kalimantan Island and Malaysia.These companies cleared land without considering season calendaras indigenous peopleof Dayak did. As a result, forest fire is uncontrollable that cause serious haze disaster. In contrast, the Dayak people have local wisdom called bambi'ari to prevent forest fire. According to bambi 'ari, Dayak people clear small scale land and use season calendar before fire the forest.This research concern swith bambi 'ari's implementation to prevent forest fire haze by using qualitative method to collect primary data. This research argues that as a local wisdom, bambi 'ari was built upon collaboration among the Dayak people to develop social solidarity. Since the Dayak people rely heavily on natural resources, they set a system to help natural resources management, such as forest. This set of system called tembawang, applies season calendar to determine planting in the field and land clearing. Forest fire as a tool of land clearing, conducted in natural ways and in particular time to avoid haze disaster. Collaboration among the Dayak people occurred when they fire forest by monitoring hot spots and supplying water to prevent uncontrolled forest fire. This research concludes that the implementation of bambi'ari as a long term natural resources management by the Dayak people enable haze disaster prevention
\end{abstract}

Keywords : Dayak People, Tembawang, Bambi 'Ari and Local Wisdom 


\section{Intisari}

Bencana kabutasapyang terjadidiKapuas Hulu disebabkan oleh pembakaran hutan untuk membuka lahan baru. Mayoritas pelakunya perusahaan yang membakar dalam skala massif dan tidak menggunakan kalender musim. Masyarakat Dayak pun melakukan pembakaran hutan dalam skala kecil dengan menggunakan konsep bambi ‘ari untuk mencegah terjadinya kebakaran hutan. Penelitian ini hendak mengkaji bagaimanakah implementsai bambi ari' dalam penanganan bencana kabut asap. Metode penelitian kualitatif untuk mendapatkan data primer dari masyarakat Dayak tentang bagaimana mengelola hutan. Hasil penelitian menunjukan bahwa masyarakat Dayak memiliki kearifan lokal dalam mengelola sumber daya alam untuk dimanfaatkan dalam kehidupan sehari-hari. Pengelolaan hutan untuk kehidupan sehari-hari dengan sistem tembawang yang mengenal kalender musim untuk proses penanaman di ladang. Pembakaran hutan sebagai bagian dari pembukaan lahan dilakukan dengan cara dan waktuyang tepatsehingga secara alami tidak menimbulkan bencana. Pada saat proses pembakarran hutan dilakukan dengan melibatkan banyak orang (keluarga atau komunitas) dengan menjaga titik-titik yang rawan terbakar dan menyediakan air untuk mencegah kebakaran hutan. Konsep bekerja bersama dan membangun solidaritas sosial tersebut yang mereka namakan bambi 'ari. Sistem ini memungkinkan pengelolaan alam dalam jangka panjang dan menggunakan tanda-tanda alam dalam prosesnya, yang mampu untuk mencegah timbulnya bencana kabut asap.

Kata Kunci : Etnis Dayak, Tembawang, Bambi Ari dan Kearifan Lokal

\section{Pendahuluan}

Kabut asap merupakan bencana yang rutin terjadi pada Musim Kemarau di beberapa wilayah di Indonesia, termasuk di Kabupaten Kapuas Hulu, Kalimantan Barat. Penyebabnya karena pembakaran hutan yang merata di wilayah tersebut. Pembakaraan hutan dilakukan untuk membuka lahan baru atau sebagai bagian dari proses siklus perladangan. Pembakaran sebagai bagian dari siklus perladangan, dilakukan setelah proses penebangan pohon dengan merobohkan 
kayu-kayu yang sudah cukup besar, biasaya diameter tanaman bisa mencapai $20 \mathrm{~cm}^{2}$. Pada skala kecil pembakaran lahan tidak menimbulkan kabut asap, akan tetapi pembakaran pada skala luas menimbulkan kabut asap yang merata. Terutama proses pembakaran hutan yang dilakukan oleh perusahaan-perusahaan dalam skala massif.

Pada bulan Juli-September tahun 2015 ini, bencana kabut asap di Kapuas Hulu merupakan kejadian yang paling parah dibandingkan dengan tahun sebelumnya. Terutama bencana yang terjadi pada tahun 1997 sebagai bencana kabut asap yang paling parah. Bencana kabut asap tersebut menyebabkan meningkatnya indeks pencemaran pada level yang membahayakan. Kenaikan indkes tersebut ditandai dengan kondisi cuaca pada saat itu yang benar-benar panas dengan sebaran titik api yang menjadikan kepakatan kabut asap makin lama makin tebal. ${ }^{1}$ Menurut Debby, anggota BMKG wilayah Pontianak menyatakan bahwa berdasarkan prakiraan BMKG Supadio dari pantauan satelit Modis terdapat sekitar 248 titik api di seluruh Kalimantan Barat, dengan sebaran di Kabupaten Kapuas Hulu sebanyak dua titik, Ketapang sebanyak 123 titik, Kubu Raya sebanyak 58 titik, Mempawah sebanyak 35 titik, Kayong Utara sebanyak 16 titik, Landak sebanyak satu titik, Melawi sebanyak satu titik, Sambas sebanyak satu titik, Sanggau sebanyak empat titik dan Sintang sebanyak tujuh titik. ${ }^{2}$

Sebaran titik api tersebut menyebabkan kabut asap semakin tebal. Kabut tebal senantiasa menyelimuti udara di seluruh Provinsi Kalimantan Barat. Beberapa gedung tinggi dan jembatan tol di Kapuas satu yang berada di Jantung kota Pontianak Timur dan Selatan menjadi tidak nampak dikarenakan kabut asap tersebut. Demikian halnya, bangunan Masjid Raya Mujahidin, Gereja Katedral Santo Yosef Pontianak, Gedung Bank Kalimantan Barat dan Masjid Jihad serta sejumlah perhotelan bertingkat tertutup oleh kabut asap. Jalanan, pusat-pusat perkantoran, perdagangan dan jasa pun bernasib sama dengan gedung pencakar langit tersebut.

Pada situasi tersebut, masyarakat yang mengendarai kendaraan bermotor wajib menyalakan lampu untuk keselamatan pengendara. Situasi yang sama, terjadi di wilayah perairan Sungai Kapuas sebagai penghubung jalan utama. Kendaraan bermotor, terutama kapal motor wajib menghentikan operasi kapal motornya untuk menghindari

1 (http://m.detik.com/news/berita/3021114/bencana-kabut-asap-kianparah-di-pontianak-berikut-penampakannya).

2 http:/ / googleweblight.com/?lite_url=http://m.antaranews.com/ berita/519726/ kabut-asap-tebal-kembali-selimuti-kota-pontianak\&ei=hZ_ $\mathrm{ZXqw}$ r \& $\mathrm{lc}=\mathrm{e} n-\mathrm{ID} \& \mathrm{~s}=1 \& \mathrm{~m}=733 \& \mathrm{ts}=1447814443 \& \mathrm{sig}=\mathrm{ALL} 1 \mathrm{Aj} 7-$ JrvjHyTcfxvyDO9tbuKtF54DEA 
kecelakaan di perairan. Masyarakat nelayan tradisional secara otomatis menghentikan aktivitas melaut demi keselamatan pelayarannya. Hal yang terlihat di Bandar udara. Aktivitas di Bandar Udara Supadio mengalami kelumpuhan aktivitas secara total. Terhentinya beberapa aktivitas warga di beberapa tempat tersebut menyebabkan terjadinya kerugian ekonomi. Selain kerugian ekonomi, dampak lain secara nyata dirasakan oleh masyarakat adalah masalah kesehatan. Kurang lebih 7.000 jiwa warga Pontianak, terutama anak-anak, banyak yang terserang infeksi saluran pernafasan akut (ISPA).

Situasi bencana kabut asap yang merugikan hampir seluruh warga masyarakat tersebut, mendorong berbagai pihak untuk bahu membahu saling memberikan pertolongan. Salah satu pihak tersebut adalah pemerintah kota Pontianak. Menurut Wakil WaliKotaPontianak, Edy Rusdi Kamtono, Pemerintah Kota Pontianak melakukan upaya penanganan dampak bencana dengan membagikan ribuan masker kepada masyarakat yang mengalami efek bencana. Selain masker, pemerintah kota juga menyiapkan alat-alat kesehatan yang diperlukan, kesiapan SDM serta obat-obatan untuk penderita ISPA. Pemerintah melalui rumah sakit dan puskesmas juga menyiapkan obat-obatan dan logistik alat-alat kesehatan. ${ }^{3}$

Sisi lain, masyarakat lokal (masyarakat yang berasal dari Etnis Dayak) sebenarnya memiliki tradisi untuk mengatasi persoalan bencana kabut asap yang dilakukan secara alami. Mereka memiliki konsep kalender musim secara alami yang dilakukan secara bambi ari' sebagai salah satu bentuk tradisi kolektivitas dan kearifan lokal sebagai upaya untuk menyelesaikan permasalahan bersama. Hal yang menarik untuk dikaji adalah bagaimana konsep bambi ari' ini diterapkan dalam menyelesaikan permasalahan bencana kabut asap.

\section{Penyebab dan Kerugian Bencana Asap}

Kebakaran hutan yang terjadi di Kalimantan Barat pada awalnya terjadi pada pertengahan tahun 1997. Bencana di tahun tersebut merupakan titik awal mula parahnya bencana kabut asap di Indonesia karena mengakibatkan terbakarnya lahan seluas 9juta hektar. ${ }^{4}$ Kerugian materiil yang dialami oleh beberapa negara, yaitu: Indonesia, Malaysia dan Singapura karena bencana tersebut diperkirakan mencapai 4,5

3 (http:// m.okezone.com/read/2015/09/30/340/1223396/kabut-asap-7000-warga-pontianak-derita-ispa)

$4 \mathrm{~h} \mathrm{t} \mathrm{t} \mathrm{p} \mathrm{:} \mathrm{/} \mathrm{/} \mathrm{w} \mathrm{w} \mathrm{w.} \mathrm{harianter} \mathrm{bit.com/} \mathrm{m} \mathrm{/} \mathrm{n} \mathrm{a} \mathrm{sion} \mathrm{a} \mathrm{l} \mathrm{/}$ $\mathrm{read} / 2015 / 1125 / 48600 / 0 / 25 /$ fakta-bencana-asap-tahun-1997-lebih -parah-daritahun-2015 
Billion US \$ atau setara dengan Rp 9 Milyar pada saat itu..$^{5}$ Sementara itu, bencana kabut asap yang terjadi pada tahun 2015 menyebabkan kebakaran lahan seluas 2,6 juta hektar, dengan rincian: 1,74 hektar (67\%) merupakan tanah mineral dan 0,87 hektar (33\%) merupakan tanah gambut. ${ }^{6}$

Dampakbencanakabutasaptersebutmenyebabkanterganggunya kesehatan, aktivitas ekonomi dan pariwisata bagi masyarakat. Dampak pada kesehatan dengan munculnya berbagai macam penyakit. Penyakit yang disebabkan oleh kabut asap, diantaranya: (1) infeksi saluran pernafasan. Penyebab utamanya virus yang diperparah polusi udara yang menyebabkan gangguan pernafasan; (2) asma, yang diperparah dengan buruknya cuaca; (3) penyakit paru-paru obstruktif kronik sebagai bentuk penyakit gabungan dari bronchitis; (4) penyakit jantung, yang dipicu oleh kabut asap yang membawa partikel mini melalui saluran pernafasan; dan (5) iritasi pada mata, hidung, sakit kepala, tenggorokan dan menyebabkan alergi. ${ }^{7}$

Dampak kerugian ekonomi dari kabut asap ini tidak hanya merugikan masyarakat di Kalimantan Barat, akan tetapi juga merembet ke negara tetangga, khususnya di Malaysia dan Filipina. Beberapa bandar udara, diantaranya: Palawan dan Puerto Princesa yang ditutup penerbangannya selama kabut asap berlangsung. Sektor pariwisata juga mengalami imbas dari bencana kabut asap ini, dengan jumlah kerugian yang tidak sedikit. Kerugian tersebut, terutama yang berasal dari penurunan angka hunian hotel dan biro perjalanan dengan kerugian mencapai $\operatorname{Rp} 4,89$ miliar.

Kerugian lainnya dengan terhentinya aktivitas perekonomian masyarakat, baik industri, perdagangan, pertanian atau pun perkebunan sebagai dampak ekonomi tidak langsung, mencapai kurang lebih sebesar Rp 25,69 miliar. Pemerintah juga melakukan usaha pencegahan pencemaran dengan pembelian masker dengan jumlah biaya yang tidak sedikit. Kerugian tidak langsung lainnya dari kebakaran hutan ini adalah munculnya kabut asap yang menyebabkan menurunnya kualitas tanaman serta keanekaragaman hayati, baik flora maupun fauna sebagai efek jangka panjang dari bencana yang berkelanjutan.

5 (Perkiraan ini dibuat pada bulan Mei 1998 oleh The Singapore based Economy and Environment Programme for Southeast Asia (EEPSEA) dan World Wide Fund for Nature (WWF); seperti yang termuat dalam Indonesia Fires and Haze of 1997 : The Economic Tool, (1998).

6 Op.cit, www.harianterbit.com

7 http://m.dw.com/id/nasa-kabut-asap-indonesia-terparah-dalam -sejarah/a-1875 
Kabut asap yang terjadi disebabkan oleh banyak faktor antara lain kebakaran hutan, polusi kendaraan bermotor, pabrik, letusan gunung berapi, pembakaran sampah rumah tangga dan yang paling dominan adalah kebakaran hutan rutin seiring dengan aktivitas pertanian dan perkebunan. Kebakaran hutan tersebut disebabkan oleh dua hal, yaitu: (1) adanya deposit batu bara di setiap hutan tropis di Indonesia, yang mempermudah munculnya titik-titik api baru setiap tahunnya; dan (2) perilaku masyarakat peladang yang terbiasa menggunakan metode slash and burn $^{8}$ dalam membuka lahan baru dan meningkatkan kesuburan tanah. Metode membakar tersebut dipilih oleh masyarakat peladang tradisional berdasarkan perhitungan ekonomis karena metode tersebut berbiaya rendah dan dapat dilakukan oleh siapa saja tanpa harus memiliki keahlian tertentu.

Metode yang murah ini kemudian diadopsi oleh perusahaan perkebunan. ${ }^{9}$ Adanya kepentingan beberapa perusahaan pada tingkat Multi National Corporation (MNC) yang melakukan pembakaran hutan dalam skala massif, menimbulkan beberapa titik api pada wilayah konsesi yang dikuasi dengan Hak Pengelolaan Hutan (HPH) dan Hutan Tanaman Industri (HTI). Aktivitas ini menyebabkan kebakaran hutan semakin parah. Pada tahun 2004 tercatat ada 10 perusahaan pemegang HPH melakukan kegiatan pembakaran hutan dan lahan yang tersebar pada 24 titik api di sekitar Kalimantan Barat. ${ }^{10}$ Menurut catatan Wahana Lingkungan Hidup Indonesia (WALHI) terdapat 54 Perusahaan yang melakukan pembakaran hutan dan lahan, terdiri dari 30 di kawasan HPH, 8 di kawasan Hutan Tanaman Industri (HTI) dan 26 di kawasan Perkebunan. ${ }^{11}$

Metode pembakaran yang murah tersebut biasanya digunakan untuk: (1) upaya konversi lahan perkebunan ke kelapa sawit. (Faktnya, penanaman modal asing di bidang kelapa sawit mengalami peningkatan yang cukup signifikan. Pada tahun 1980-an tercatat terdapat 0,8 juta hektar, sedangkan lahan kelapa sawit pada tahun 2004

8 Lesley Potter, Forest Degradation, Deforestation and Reforestation in Kalimantan: Towards a Sustainable Land Use?, in Borneo In Transition: People, Forests, Conservation and Development 13, 24 (Christine Padoch \& Nancy L. Peluso eds.,1996.

9 Lihat Office of the State Minister for the Environment \& United Nations Development Programme, Forest and Land Fires in Indonesia, Vol. 1: Impacts, Factors and Evaluation, hlm. xi (1998).

10 Lihat "Kebakaran Di Taman Nasional Berbak Meluas", Suara Pembaruan (31 Agustus 2004)

11 Lihat pula WALHI, "Perusahaan Pelaku Pembakaran Hutan 2004" terdapat di alamat http://www.walhi. or.id/kampanye/bencana/bakarhutan/ diakses pada tanggal 11 Januari 2012) 
meningkat mencapai 5,3 juta hektar ${ }^{12}$; (2) industri perkebunan dan palawija (faktanya, industri perkebunan dan hasil kayu merupakan salah satu cabang industri penyumbang terjadinya deforestasi); ${ }^{13}$ dan (3) pembukaan lahan untuk program transmigrasi dari penduduk dari Pulau Jawa di Kalimantan. ${ }^{14}$

\section{Tradisi Masyarakat Dayak}

\section{Sistem Kehidupan Masyarakat Dayak}

Istilah Dayak berarti orang udik. Mereka merupakan orang asli Etnis Melayu di Kalimantan, Indonesia dan Sabah-Serawak, Malaysia. Istilah kata Dayak lebih disukai dibandingkan dengan istilah kata yang lain, misalnya: Kayan, Kenyah, Benuaq, Lun Dayeh dan Punan. Secara tradisional, komunitas Dayak tinggal di rumah panjang secara kolektif (lamin), dimana banyak keluarga dalam satu klan yang tinggal bersama di bawah satu atap. Setiap rumah panjang memiliki seorang ketua adat yang mengatur kepemilkan sumberdaya komunitas termasuk Bengkar atau sumberdaya hutan dan Simpukng (kebun hutan). Komunitas Dayak memiliki struktur sosial yang komplek. Akan tetapi, pada masa modern ini, strata sosial tersebut mengalami perubahan karena intervensi politik, perdagangan dan aktivitas pembangunan.

Masyarakat Dayak mempercayai bahwa keberadaan sumber daya alam sangat penting untuk eksistensi manusia. Tanah dan orang memiliki hubungan ketergantungan sebagai salah satu bentuk filosofi mendasar yang melekat pada komunitas Dayak. Latitana atau tanah hutan merupakan konsep manajemen penggunaan tanah yang berhubungaan dengan berbagai macam aspek kehidupan, yaitu: agama, kekeluargaan, sosial dan ekonomi. Komunitas Dayak sangat peduli dengan sumber daya alam dan mereka melakukan konservasi secara berkelanjutan. ${ }^{15} \mathrm{Hal}$ ini berdampak pada aktivitasnya yang tidak bisa dipisahkan dengan alam, diantaranya: berburu, mengumpulkan madu, kayu kamfer, kacang dan berburu burung, mengumpulkan hasil hutan selain kayu yang berguna dalam kehidupannya. Aktivitas

12 Lihat Charles V. Barber \& James Schweithelm, Trial by Fire: Forest Fires and Forestry Policy in Indonesia's Era of Crisis and Reform (2000))

13 Lihat Christopher Barr, Banking on Sustainability: Structural Adjustment and Forestry Reform in Post-Suharto Indonesia 60, 70-96.)

14 Op.Cit, Charles V. Barber \& James Schweithelm, Trial by Fire: Forest Fires and Forestry Policy in Indonesia's Era of Crisis and Reform (2000).

15 Elok Mulyoutami, Ratna Rismawan 1, Laxman Joshi, Local knowledge and management of simpukng (forest gardens) among the Dayak people in East Kalimantan, Indonesia World Agroforestry Centre (ICRAF), Southeast Asia Regional Office, 2009 
Masyarakat Dayak Benuaq yang bertahan hidup dengan cara berburu, menyebabkan sumber daya hutan merupakan komponen penting dalam kehidupannya. Pada saat kegiatan berburu dilakukan dengan menggunakan metode: nganup, mabang, ngusi, menggunakan jebakan, belatik, serung, lubang pesut, tepap, labak. Sedangkan, kegiatan menangkap ikan secara khusus dilakukan dengan menggunakan: tuba, jala, bubu dan pancing.

Saat ini, mayoritas masyarakat Dayak mempraktikan kehidupan tradisional, yaitu: pertanian menetap dengan melakukan penebangan kayu secara bergantian di beberapa lahan. Mereka dengan sengaja menebang pohon buah-buahan yang berada di hutan untuk dikonsumsi. ${ }^{16}$ Akan tetapi, mayoritas masyarakat Dayak masih menerapkan kegiatan ekonomi yang belum menetap, yakni aktivitas berladang, menangkap ikan dan meramu. Kegiatan berladang ini dilakukan pada lahan dengan varietas tanaman kurang lebih 51 jenis, termasuk 12 varietas padi ketan. Di dalam pemilihan tempat berladang, kebiasaan lama yang dilakukan yaitu memeriksa tandatanda di hutan yang akan dijadikan ladang, seperti memeriksa apakah ada sejenis rumput rendah, misalnya: udu pengenan, keadaan tanah yang sebaiknya batunya sedikit atau tidak berbatu dan ada tidaknya aliran sungai yang dekat dengan tempat berladang. Pada saat berladang yang diutamakan adalah bekas ladang sebelumnya yang sudah dibiarkan menjadi hutan kembali yang disebut jekau, dengan selang waktu selama kurang lebih 8-9 tahun. Bekas ladang yang baru satu tahun tidak digunakan lagi disebut bekan. Sementara itu, lahan jekau merupakan wilayah yang akan dijadikan ladang harus memiliki persyaratan khusus, misalnya: umbut tidak terlalu banyak, daundaunan yang ada haruslah ada daun benaung, pohon kayu haruslah sebesar daun pisang.

Pada proses berladang ini, mereka masih dipengaruhi oleh kepercayaan amen-amen dan Adat Bungan. Adat tersebut mensyaratkan beberapa pantangan yang mengakibatkan pembatalan ladang, misalnya: (1) bunyi kijang, (2) burung isit dan (3) kukang. Apabila bertemu dengan ketiganya pembukaan ladang dibatalkan. Apabila persyaratan telah dipenuhi, maka tahap pemeriksaan hutan sudah selesai, yang dilanjutkan dengan kegiatan persiapan ladang, diantaranya: (1) menebas (midik); (2) menebang (menepang); (3) memotong dahan (meto); (4) menjemur tebangan pohon (pegang); dan (5) membakar ladang (untung).

Pada saat proses pembakaran ladang, sebelumnya dilakukan 16 Lawrence et al., 1995 dalam Elok Mulyowati 
dengan melakukan pengamanan di sekitar ladang yang akan dibakar, yaitu dengan membersihkan lahan di sekeliling lahan dari dahan, ranting, daun dengan lebar kurang lebih 1 meter, dengan tujuan agar api tidak merambat ke hutan. Cara pembakaran dilakukan dengan mempelajari arah angin yang bertiup di ladang tersebut. Api harus disulut berdasarkan arah angin. Pembakaran harus dilakukan secara serentak oleh orang-orang yang memiliki ladang berdekatan secara serentak sehingga semua ladang habis terbakar dan api tidak merambat kemana-mana. Pasca pembakaran, aktivitas masyarakat lainnya adalah: membakar sisa (mekup), menanam padi (menugan), senguyun, pulun, mabe, merumput (mabau), memanen dan membuat kelimeng. ${ }^{17}$ Sedangkan, sistem pemanenan bervariasi dalam jangka panjang yang dikerjakan oleh masyarakat Dayak. Beberapa komunitas menanam umbi-umbian dan padi non irigasi. ${ }^{18}$

\section{Kalender Musim Masyarakat Dayak}

Masyarakat Dayak memiliki konsep sendiri dalam menentukan waktu berladang. Ketentuan yang mereka gunakan berdasarkan kalender alam. Mereka memilah bulan berladang pada bulan ke-4 sampai bulan ke-6, sebagai awal kegiatan berladang. Masa itu merupakan waktu untuk penyiapan lahan. Pada bulan ke-4 ditandai dengan adanya buaya mulai naik ke darat untuk bertelur. Bulan ke-6 ditandai dengan munculnya "bintang tiga" pada dini hari seperti kedudukan matahari jam 09.00 pagi bertepatan dengan bulan Juli, pada saat kegiatan penebangan telah selesai. Prosesnya kemudian dilanjutkan dengan pembakaran. Pada bulan ke-7 sampai bulan ke-9 saatnya menyemai benih, yang ditandai dengan adanya bintang-bintang ribuan jumlahnya yang muncul secara periodik. Tanda alam tersebut diyakini oleh masyarakat di Kalimantan Barat sebagai pertanda akan datangnya air pasang atau mulainya air surut. ${ }^{19}$ Masyarakat mengenal adanya bintang Baur Bilah yang apabila muncul di ufuk barat pada senja hari menandai akan terjadinya kemarau panjang atau pendek dan sebaliknya apabila yang muncul bintang Karantika menandakan

17 Cristina Eghenter dan Bernard Sellato: Kebudayaan dan Pelestarian Alam: Penelitian Interdisipliner di Pedalaman Kalimantan, 1999, Jakarta WWF Indonesia.

18 Sellato 2001 dalam Elok Mulyowati

19 (Wisnubroto, S. dan R. Attaqi. 1997. Pengenalan waktu tradisional "Bulan Berladang" kesamaaannya dengan keadaan meteorologis dan pemanfaatannya untuk pertanian. Jurnal Ilmu Tanah dan Lingkungan:1(1), Desemeber 1997: Hlm. 6166. Fak. Pertanian Univ. Gadjah Mada. Yogyakarta.) 
tibanya musim hujan. ${ }^{20}$

Secara lebih detil, masa berladang masyarakat di Kapuas Hulu sebagaimana tertulis pada tabel 1. Berdasarkan tabel 1 tersebut, secara lebih detil proses bercocok tanam (berladang) masyarakat Dayak dapat diuraikan sebagai berikut:

1. nebas merupakan proses awal membersihkan ladang untuk memulai masa tanam. Proses ini dilakukan secara bersama-sama dengan seluruh warga yang dikenal dengan konsep bambi' ari untuk membersihkan ladang secara bersama-sama.

2. nebang merupakan proses menebang kayu-kayu besar di ladang sebagai awal membuka lahan baru. Pekerjaan menebang merupakan salah satu pekerjaan berat dan berbahaya, sehingga secara umum pekerjaan ini dilakukan oleh laki-laki. Mereka juga menggunakan konsep bambi' ari dalam proses ini.

3. bakar (nutung) merupakan proses membakar kayu-kayu yang sudah ditebang pada proses sebelumnya (nebang). Pada proses pembakaran ladang biasanya orang yang punya ladang dibantu oleh beberapa masyarakat lainnya. Proses pembakaran lahan dilakukan secara ramai-ramai dengan menggunakan konsep bambi 'ari. Hal ini dilakukan untuk menghindari meluasnya api ke tempat-tempat lain yang bukan ladang masyarakat. Apabila perluasan pembakaran lahan terjadi, orang yang punya ladang bisa terkena hukum adat dengan besaran yang telah ditentukan, apalagi kalau tempat yang terbakar itu kebun orang lain hukumannya sangat besar. Mereka terlebih dahulu membersihkan keliling ladang mereka, terutama pada titik-titik yang rawan untuk menghindari terjadinya perluasan lahan yang terbakar. Mereka juga waspada dengan menyiapkan air di setiap titik-titik rawan. Kewaspadaan tersebut menjadi salah satu faktor yang menunjukan bahwa pembakaran lahan yang dilakukan oleh masyarakat tidak menyebabkan terjadinya perluasan lahan yang terbakar, apalagi menyebabkan terjadinya bencana kabut asap.

4. nyiang merupakan proses membersihkan ladang setelah dibakar. Nyiang disebut juga nyorak. Proses ini dilakukan oleh warga secara bersama-sama, baik itu laki-laki maupun perempuan, bahkan tidak jarang anak-anak terlibat didalamnya. Kegiatan ini dilakukan untuk membersihkan kembali potongan-potongan kayu sisa bakaran dan membakarnya kembali, selain itu pada proses ini masyarakat membuat batas-batas dari kayu untuk memberi batas pada setiap jenis padi yang akan ditanam.

20 (Noorginayuwati dan Rafieq, 2007) dalam Wisnubroto, 1997 
5. nuhujak atau nugal merupakan proses menanam benih yang sudah dipersiapkan sebelumnya. Nuhujak atau nugal merupakan proses penanaman benih dengan adanya pembagian tugas antara laki-laki dan perempuan. Laki-laki bertugas menugal atau membuat lubang tempat menjatuhkan benih, sementara untuk kelompok ibu-ibu bertugas menjatuhkan benih atau menanam benih pada lubang yang telah dibuat oleh kelompok laki-laki, sesuai dengan batas dan jenis padi yang telah ditentukan.

6. ngulu' atau ngerumput merupakan proses membersihkan tanaman padi dari hama tanaman (rumput) yang tumbuh di sekitar ladang (pada padi sebagai tanaman utama). Ngulu' dilakukan dengan cara bersama-sama terutama oleh kelompok ibu-ibu.

7. ngotom merupakan sebutan untuk masa panen. Proses panen dilakukan dengan konsep bambi' ari, baik itu laki-laki maupun perempuan. Untuk proses panen ini biasanya terjadi sekitar bulan Februari dan Maret. Panen dilakukan pada bulan tersebut karena padi yang ditanam warga merupakan jenis padi tahunan. Pada masa panen ada hal menarik yang dilakukan warga terutama dalam menentukan benih yang ditanam selanjutnya. Pertama, untuk menentukan seleksi benih saat masih di kebun. Seleksi dilakukan untuk menentukan varietas padi mana yang akan mereka jadikan benih selanjutnya. Mereka melakukan dengan cara memilih dan melihat pada titik atau kelompok mana bulir padi yang paling baik, lebat dan subur. Setelah mereka menentukan titiknya, mereka akan mengepung titik tersebut dengan tidak memanennya. Kedua, proses panen benih dilakukan di akhir panen, pada saat daun-daun padi mulai terkulai layu dan bahkan mati. Ketiga, untuk memanen benih, masyarakat sangat memperhatikan, pertanda-pertanda di sekitar mereka, seperti: mimip, suara burung dan bahkan setiap kejadiankejadian yang mereka alami. Jika belum muncul petanda alam, mereka belum memanennya sampai pada saat yang tepat. Terakhir ialah penyimpanan benih. Pada saat menyimpan benih mereka lakukan dengan cara menyimpannya pada tempat yang aman, tidak basah dan tidak jarang ada lumbung khusus penyimpanan padi dan benih (data primer 2016). 
Tabel 1

Kalender Musim Berladang Masyarakat di Kabupaten Kapuas Hulu

\begin{tabular}{|c|c|c|c|c|}
\hline No & Kegiatan & Waktu / Bulan & Alat kerja & Keterangan \\
\hline 1 & nebas (memo) & $\begin{array}{l}\text { Sekitar bulan } \\
\text { Juni }\end{array}$ & Parang & \\
\hline 2 & nebang (nong) & Akhir bulan Juni & $\begin{array}{l}\text { Parang, } \\
\text { Beliung, } \\
\text { Kapak, } \\
\text { Tinso }\end{array}$ & $\begin{array}{l}\text { nebang adalah } \\
\text { merobohkan } \\
\text { kayu-kayu yang } \\
\text { sudah cukup } \\
\text { besar, biasaya } \\
\text { diameter } \\
\text { tanaman bisa } \\
\text { mencapai } 20 \mathrm{~cm}\end{array}$ \\
\hline 3 & bakar (nutung) & $\begin{array}{l}\text { Awal sd. } \\
\text { pertengahan } \\
\text { bulan Agustus }\end{array}$ & $\begin{array}{l}\text { Obor dan } \\
\text { air }\end{array}$ & \\
\hline 4 & nyiang (ngorak) & $\begin{array}{l}\text { Awal sd. } \\
\text { pertengahan } \\
\text { bulan Agustus }\end{array}$ & $\begin{array}{l}\text { Api, } \\
\text { Kapak } \\
\text { dan Tinso }\end{array}$ & \\
\hline 5 & nugal (nuhujak) & $\begin{array}{l}\text { Pertengahan } \\
\text { bulan Agustus } \\
\text { sampai awal } \\
\text { bulan September }\end{array}$ & $\begin{array}{l}\text { Tubujak } \\
\text { dan benih }\end{array}$ & \\
\hline 6 & $\begin{array}{l}\text { ngerumput } \\
(\text { ngulu') }\end{array}$ & $\begin{array}{l}\text { Pada bulan } \\
\text { Oktober }\end{array}$ & Parang & \\
\hline 7 & panen (ngotom) & $\begin{array}{l}\text { Antara bulan } \\
\text { februari sd } \\
\text { Maret }\end{array}$ & $\begin{array}{l}\text { Songetan, } \\
\text { Itoh } \\
\text { (Tangkin), } \\
\text { Talaung } \\
\text { (Tanggoi) }\end{array}$ & \\
\hline
\end{tabular}

8 a. seleksi benih Dipilih padi yang paling bagus atau subur, namun memiliki banyak pantangan.

Diantaranya: hujan panas, kayu tumbang, mimpi buruk dan api padam.

b. penyimpanan benih disimpan dalam pasu, pada tempat yang benih kering dan kira-kira aman

Sumber: Data primer, 2016 
Mengkaji proses-proses bercocok tanam yang dilakukan oleh masyarakat Dayak, mulai dari nebas (membuka ladang) sampai pada saat ngotom (panen) merupakan bagian dari kegiatan komunitas yang bersahabat dengan lingkungan. Proses bercocok tanam dilakukan dengan memperhatikan bagaimana keberlanjutan lingkungan alam tetap bisa berlangsung. Pemahaman ini mengemuka karena secara tidak langsung mereka menyadari bahwa bercocok tanam merupakan salah satu bagian dari permasalahan ekologi yang tidak bisa dipisahkan dari kehidupan manusia. Mengingat adanya faktor dualisme manusia sebagai makhluk biologis dan makhluk sosial. Makhluk biologis tentunya berkaitan dengan unsur-unsur makhluk hidup (hewan dan tumbuhan), sementara makhluk sosial yang berkaitan dengan unsur-unsur yang berkaitan dengan makhluk-makhluk tidak hidup, misalnya: air, udara, tanah dan lingkungan hidup lainnya.

Proses bercocok tanam itu dilakukan untuk mencukupi kebutuhan hidupnya sehari-hari dan tidak dalam skala yang massif. Proses berladang dilakukan di lokasi lahannya sendiri dalam skala kecil dan melibatkan banyak orang dalam setiap prosesnya untuk menghindari terjadinya kerusakan alam, terutama kebakaran hutan. Mereka melakukan proses bakar (nutung) karena pada proses ini tidak membutuhkan biaya besar. Namun demikian, mengingat pembakaran yang dilakukan tidak pada skala besar disertasi dengan kewaspadaan masyarakat dengan menyediakan air pada setiap titik, bencana kebakaran hutan dan kabut asap dapat dihindarkan. Apabila apinya diperkirakan meluas, mereka segera bahu membahu memadamkan api tersebut.

Nilai-nilai yang bisa diambil dari beberapa proses bercocok tanam oleh masyarakat Dayak ini adalah nilai ketergantungan terhadap alam (proses yang mereka lakukan sangat tergantung pada alam), mengambil sumber daya alam yang secukupnya (proses bercocok tanam dilakukan di ladang mereka sendiri dalam skala kecil yang sudah dibagi sesuai dengan hukum adat) dan pada proses mengelola alam tidak dilakukan secara sendiri, akan tetapi bersama-sama dengan kelompok masyarakat lain secara kolektif dengan tradisi yang dikenal dengan sebutan bambi 'ari. Secara detil, berdasarka perspektif ekologi, hubungan antara antara manusia dengan lingkungan alam dan lingkungan sosialnya pada komunitas Dayak dapat dijelaskan sebagai berikut:

\section{Saling tergantung (interdependency)}

Kesalingtergantungan dalam perspektif ekologi terjadi antara 
komponen yang ada dalam ekosistem terjadi antar komponen yang terlibat di dalamnya. Komponen yang dimaksud terjadi antar makhluk hidup serta makhluk hidup dengan sesuatu hal yang tidak hidup yang tidak bisa dipisahkan satu dengan yang lainnya. Ketergantungan ini nampak bagaimana ketergantungan masyarakat terhadap hutan yang sangat tinggi, sehingga kehidupan sehari-hari dan sumber ekonominya berasal dan berkembang dari sumber daya hutan.

2. Jaring kerja (networks)

Pola kehidupan yang terjadi pada setiap organisme merupakan sebuah rangkaian kerja yang sistematis yang mencakup jaring kerja dari organ. Setiap organ merupakan jaring kerja dari sel dan setiap sel merupakan jaring kerja dari berbagai komponen. Pada setiap jaring kerja melibatkan adanya kerjasama, kemitraan dan kolaborasi yang melibatkan antar komponen tersebut. Jarring kerja ini ditunjukan dalam proses pengelolaan sumber daya hutan secara kolektif untuk meringankan pekerjaan serta untuk menghindari terjadinya bencana alam yang mengancam kehidupan manusia pada skala besar. Nampak dari semua proses, mulai dari pembukaan ladang sampai dengan masa panen dilakukan secara bersama-sama.

\section{Keseluruhan (holistic)}

Setiap kejadian alam tidak bisa dipisahkan dan merupakan bagian dari peristiwa lainnya yang lebih besar. Kejadian alam tidak bisa terjadi dengan sendirinya karena selalu ada sebab akibat dalam setiap peristiwa atau kejadian tersebut. Kesalinghubungan tersebut sebagai implikasi dari prinsip saling ketergantungan (Capra, 1999). Ketergantungan masyarakat Dayak terhadap sumber daya hutan yang sangat tinggi sudah disadarinya akan menyebabkan bencana alam, jika mereka tidak waspada. Kewaspadaan itu mereka tunjukan dengan melibatkan semua jaringan yang dimilikinya untuk terlibat pada setiap proses yang dilewati sampai dengan masa panen yang dinantikan. Bencana alam tersebut bisa nampak dalam berbagai bentuk, yang tentunya tidak hanya mengganggu proses bercocok tanam mereka sendiri, akan tetapi juga menyebabkan kerugian bagi negara lain.

Perspektif ekologis tersebut menjadi sebuah paradigma baru yang menggantikan paradigm lama (mekanistik/Cartesian) dalam pengelolaan tata kelola sumber daya alam. Pandangan ekologis lebih menekankan adanya perubahan sosial dalam pengelolaan lingkungan, bukan perubahan lingkungan. Hal terpenting adalah mengubah perilaku masyarakat dalam mengelola alam untuk kesejahteraan, 
bukan merubah alam/lingkungan untuk kesejahteraan manusia. Pandangan ini mengadopsi pemikiran Ulrich Beck (1994) bahwa situasi saat ini, masyarakat modern sangat beresiko, yang berpotensi merusak alam dengan penggunaan teknologi yang bersifat eksploitatif.

\section{Sistem Sosial Bambi Ari}

Konsep budaya bambi' ari yang dipraktikan oleh komunitas Dayak merupakan proses kerjasama yang dilakukan oleh beberapa orang dalam suatu masyarakat untuk mengerjakan suatu pekerjaan dengan cara bergiliran dengan jenis pekerjaan yang sama dengan tujuan untuk mempercepat proses pekerjaan dengan hasil maksimal dari kegiatan yang dilakukan. Budaya bambi' ari dalam bahasa Indonesia artinya hampir sama dengan konsep semangat gotong royong. Pada konsep masyarakat Dayak ini, gotong royong merupakan bagian dari bambi' ari, karena konsep gotong royong hanya dapat dilakukan pada kegiatan sosial belaka. Sementara konsep bambi' ari selain dilakukan untuk kegiatan sosial juga dilakukan untuk aktivitas berladang, perekonomian, pembangunan dan bahkan dapat dilakukan juga dalam acara perkawinan, gawai (punya hajat), ataupun pada peristiwa kematian.

Budaya bambi' ari ini dilakukan secara sukarela dan dengan semangat kekeluargaan tanpa adanya paksaan yang mengikat dari orang lain atau dari pihak manapun. Namun demikian, walaupun bukan suatu tuntutan wajib, akan tetapi masyarakat mengakui sebagai suatu bentuk toleransi terhadap masyarakat lain yang sudah dijalankan secara turun temurun oleh komunitas Dayak di Kabupaten Kapuas Hulu. Kegiatan ini bersifat sukarela dan sebatas kebiasaan yang sering dilakukan oleh masyarakat sehingga tidak mempunyai sanksi yang kuat. Budaya ini memiliki nilai-nilai sosial yang dapat memperkuat rasa kebersamaan, rasa senasib-sepenanggungan, kekeluargaan, kesadaran bersama dan menciptakan budaya malu di kalangan masyarakat, apabila tidak terlibat dalam satu aktivitas yang melibatkan budaya bambi 'ari.

Budaya malu yang tumbuh dalam komunitas Dayak menimbulkan tanggung-jawab sosial di kalangan sesama anggota komunitas. Hal tersebut merupakan nilai-nilai tradisi yang sangat penting pengaruhnya terhadap aktivitas masyarakat sehari-hari. Masyarakat masih sangat terikat oleh rasa kekuatan sebagai keluarga besar dan dijiwai oleh rasa solidaritas yang sangat kuat, semangat gotong royong yang sangat tinggi, serta dalam pemecahan masalah senantiasa 
diselesaikan dengan musyawarah sesuai dengan adat istiadat masyarakat. Tradisi yang mengakar tersebut tetap dipertahankan oleh sebagian besar anggota komunitas, walaupun adanya nilai-nilai baru yang gencar mempengaruhi pandangan dan orientasi masyarakat. Pandangan dan orientasi nilai-nilai baru yang sedikit menggeser pandangan masyarakat terhadap tradisi diantaranya: ditinggalkannya adat istiadat yang bertentangan dengan ajaran agama.

Bambi ari juga diterapkan oleh masyarakat Dayak dalam aktivitas pertanian. Penerapannya dalam keluarga yang terdiri dari suami maupun istri yang anggotanya tidak terbatas, menggunakan budaya bambi 'ari ini untuk terlibat dalam aktivitas pertanian dengan jumlah orang antara 9 sampai 25 orang. Kelompok ini sangat efektif dan memudahkan proses pengolahan lahan sawah/ladang keluarga petani. Pembentukan kelompok kerja tersebut didasari oleh semangat tolong menolong dan semangat kebersamaan dalam lingkungan desa. Proses pelaksanaan bambi' ari diselenggarakan secara bergiliran, namun acak tergantung dari kesiapan masing-masing anggota kelompok tersebut. Sebagai contoh: 11 orang yang terlibat bambi' ari untuk melaksanakan suatu kegiatan. Maka hari pertama mereka bekerja bersama-sama di salah satu lahan pertanian, hari kedua dilanjutkan di lahan warga lain yang terlibat dalam budaya tersebut, selanjutnya di lahan lainnya lagi yang siap untuk proses pertanian dan sampai akhirnya ke 11 lahan dari 11 orang yang terlibat.

Pengertian kelompok kerja bambi' ari berakhir dalam satu priode tertentu, yaitu apabila ke 11 orang yang tergabung dalam satu kelompok tersebut sudah menyelesaikan pekerjaan mereka bersamasama di lokasi lahan pertanian masing-masing secara bergiliran. Namun sekali lagi untuk jumlah anggota dan siapa-siapa yang terlibat itu tidak mengikat, bisa berubah kapan pun dan jenis pekerjaan yang dilaksanakan secara bambi' ari pun juga bisa beraneka ragam. Pelaksanaan bambi' ari yang diselengarakan oleh masyarakat Dayak biasanya dilakukan pada saat pengolahan lahan pertanian (menebas lahan), menanam, merumput (menyiang), ngotom (panen) sampai proses pengangkutan hasil panen ke rumah. Kegiatan bambi' ari yang dilakukan dalam satu kelompok pertanian bukan berarti satu kali kegiatan dalam satu lahan yang bersangkutan harus selesai, akan tetapi tujuan bambi 'ari adalah untuk mengurangi beban dan mempercepat mereka dalam mengelolah lahan pertanian secara maksimal. Selain itu, melalui kegiatan bambi' ari ini dapat mempertahankan semangat kekeluargaan, kebersamaan dan saling ketergantungan satu sama lain.

Nilai-nilai tradisi bambi 'ari ini dalam konsep sosiologis bisa 
disamakan dengan karakter masyarakat tradisional dengan berbagai macam karakteristiknya. Menurut Durkheim (1964), karakter masyarakat tradisional tersebut memiliki solidaritas mekanik, yang bercirikan: (1) pembagian kerja yang rendah, (2) kesadaran kolektif yang kuat, (3) hukum represif yang dominan, (4) tingkat individualitas yang rendah, (5) pentingnya konsensus terhadap pola-pola normatif, (6) keterlibatan komunitas dalam menghukum orang yang menyimpang, (7) saling ketergantungan yang rendah dan (8) bersifat primitif.

\section{Penutup}

Masyarakat Dayak memiliki kearifan lokal dalam mengelola sumber daya alam untuk digunakan dalam kehidupan seharihari. Pengelolaan hutan untuk kehidupan sehari-hari dengan sistem tembawang yang mengenal kalender musim untuk proses penanaman di ladang. Sistem ini memungkinkan pengelolaan alam dalam jangka panjang dan menggunakan tanda-tanda alam dalam prosesnya. Pembakaran hutan sebagai bagian dari pembukaan lahan dilakukan dengan cara dan waktu yang tepat sehingga secara alami tidak menimbulkan bencana. Kabut asap yang timbul lebih banyak disebabkan oleh perusahaan yang melakukan pembakaran secara massif dengan luasan lebih besar dibandingkan dengan penggunaan lahan oleh masyarakat Dayak. Perusahaan juga menggunakan metode yang digunakan oleh komunitas Dayak dengan membakar tanpa menggunakan teknologi tepat guna, sehingga pada wilayah yang luas bisa menyebabkan terjadinya kebakaran hutan dan kabut asap.

Pengelolaan alam yang dilakukan oleh masyarakat Dayak mampu mencegah timbulnya bencana kabut asap. Menurut perspektif pengelolaan sumber daya alam, perilaku masyarakat Dayak dalam pengelolaan sumber daya alam tersebut menggunakan perspektif ekologis. Pengelolaan sumber daya alam dilakukan sesuai dengan keselarasan alam itu sendiri, bukan hanya kepentingan ekonomi semata untuk mendapatkan keuntungan yang sebesar-besarnya dari ketersediaan sumber daya alam. Pengelolaan sumber daya alam bertujuan untuk kesejahteraan manusia (sesuai kebutuhan) dengan memperhatikan kelestarian alam. Bencana alam tidak akan terjadi, apabila pengelolaan alam dilakukan selaras dengan alam. Hal ini bertentangan dengan perspektif ekonomi dalam pengelolaan pertanian dan perkebunan di Kalimantan Barat yang lebih mengutamakan keuntungan ekonomi (untuk mendapatkan keuntungan yang sebesarbesarnya) dari alam, dibandingkan dengan perspektif pengelolaan 
sumber daya alam. Hal ini perlu menjadi perenungan kita, untuk melestarikan nilai-nilai local dalam pengelolaan sumber daya alam, guna meminimalkan bencana alam yang lebih besar.

\section{Ucapan Terimakasih}

Selama proses penelitian ini saya mengucapakan terima kasih kepada LP2M UIN Sunan Kalijaga yang telah memberikan bantuan dana penelitian tahun anggaran 2016.

\section{Daftar Bacaan}

Adiwibowo, Soeryo.(2012).Teori, Konsep, Perspektif, Paradigma, Ekologi. Bogor: IPB

Aulia, Tia Oktaviani Sumarna, dan Arya Hadi Dharmawan. (2010). Kearifan Lokal dalam Pengelolaan Sumber Daya Air di Kampung Kuta: Lokal Wisdom of Water Resource Management in Kampung Kuta, Sodality: Jurnal Transdisiplin Sosiologi, Komunikasi, dan Ekologi Manusia, Desember 2010, hlm. 345-355

Barber, Charles V and Schweithelm, James, 2000, Trial by Fire: Forest Fires and Forestry Policy in Indonesia's Era of Crisis and Reform.

Barr,Christopher,1996, Banking on Sustainability: Structural Adjustment and Forestry Reform in Post-Suharto Indonesia 60, 70-96.)

Eghenter, Cristina dan Sellato, Bernard,1999, Kebudayaan dan Pelestarian Alam: Penelitian Interdisipliner di Pedalaman Kalimantan, Jakarta: WWF Indonesia.

Moleong, L, (1999), Metodologi Penelitian Kualitatif, Bandung, Remaja Rosdakarya

Monica, Wistin. (2011). Solidaritas Sosial pada Masyarakat Pluralis yang sering mengalami Bencana Banjir di Medan dengan studi pada etnis Cina, India, dan Karo di Kelurahan Polonia, Kecamatan Medan Polonia, Medan: Universitas Sumatera Utara

Mulyoutami, Elok, 2009, Local knowledge and management of simpukng (forest gardens) among the Dayak people in East Kalimantan, Indonesia World Agroforestry Centre (ICRAF), Southeast Asia Regional Office.

Ritzer, George, (2005), Teori Sosiologi Modern, Jakarta, Kencana Permana, Raden Cecep Eka, Isman Pratama Nasution dan Jajang Gunawijaya (2011). Kearifan Lokal tentang Mitigasi Bencana pada Masyarakat Baduy, Jurnal Makara Sosial Humaniora, Vol. 15, No. 1, Juli 2011: 67-76 
Potter,Lesley,1996, Forest Degradation, Deforestationand Reforestation in Kalimantan: Towards a Sustainable Land Use?, in Borneo In Transition: People, Forests, Conservation and Development.

Wisnubroto, S. dan R. Attaqi ,1997, Pengenalan Waktu Tradisional "Bulan Berladang" kesamaaannya dengan keadaan meteorologis dan pemanfaatannya untuk pertanian. Jurnal Ilmu Tanah dan Lingkungan:1(1), Desember 1997: Hlm. 61-66. Fak. Pertanian Univ. Gadjah Mada. Yogyakarta.)

Office of the State Minister for the Environment \& United Nations Development Programme, Forest and Land Fires in Indonesia, Vol. 1: Impacts, Factors and Evaluation, hlm. xi (1998).

\section{Sumber Internet :}

http:/ / m.detik.com/news/berita/3021114/bencana-kabut-asapkian-parah-di-pontianak-berikut-penampakannya.

http://googleweblight.com/ ?lite_url=http://m.antaranews.com/

berita/519726/kabut-asap-tebal-kembali-selimuti-kotapontianak\&ei=hZ_ZXqwr\&lc=en-ID\&s=1\&m=733\&ts $=14478144$ 43\&sig=ALL1Aj7-JrvjHyTcfxvyDO9tbuKtF54DEA

http://m.okezone.com/read/2015/09/30/340/1223396/kabut-asap7-000-warga-pontianak-derita-ispa

h t t p : / / w w w . harianterbit.com / m / nasional / $\mathrm{read} / 2015 / 1125 / 48600 / 0 / 25 /$ fakta-bencana-asap-tahun-1997lebih -parah-dari-tahun-2015

http:/ / m.dw.com/id/nasa-kabut-asap-indonesia-terparah-dalam -sejarah/a-1875

http://www.walhi.or.id/kampanye/bencana/bakarhutan/ diakses pada tanggal 11 Januari 2012) 
